\title{
CONTENT OF THE MAIN COMPONENTS OF ESSENTIAL OIL IN THE NEEDLES OF SCOTS PINE GROWING IN GEOGRAPHIC CULTURES
}

S. U. RABKO, Candidate of Agricultural Sciences, Associate Professor https://orcid.org/0000-0002-6892-2859, e-mail: rebko@belstu.by

L. F. POPLAVSKAYA, Candidate of Agricultural Sciences, Associate Professor e-mail: poplavskaya@belstu.by

S. A. LAMOTKIN, Candidate of Chemical Sciences, Associate Professor e-mail: lamotkin@belstu.by

Belarusian State Technological University

I. V. KIMEICHUK, postgraduate student

https://orcid.org/0000-0002-9100-1206, e-mail: i_kimeichuk@nubip.edu.ua

National University of Life and Environmental Sciences of Ukraine

V. M. KHRYK, Candidate of Agricultural Sciences, Associate Professor e-mail: hvm2020@ukr.net

Bila Tserkva National Agrarian University

V. YU. YUKHNOVSKYI, Doctor of Agricultural Sciences, Professor https://orcid.org/0000-0003-3182-4347, e-mail: yukhnov@ukr.net

National University of Life and Environmental Sciences of Ukraine

The aim of the research is to analyze the content of terpenes in the needles of trees of climatic ecotypes of Scots pine growing in geographic forest crops and to reveal the differences in the level of essential oils. The object of the research is 17 Scots pine climatypes growing in geographical plantations on the territory of the Negorelsk Educational and Experimental Forestry Enterprise of the Minsk region in Belarus. Qualitative and quantitative analysis of Scots pine needles essential oil was carried out by gas-liquid chromatography without preliminary fractionation on chromatograph "Kristall 5000.1".

In the studied climatypes of Scots pine, different levels of essential oil content among monoterpenes, sesquiterpenes and oxygen-containing groups were determined, as well as significant differences in the content of a number of components within the studied groups were revealed. The highest yield of essential oil is observed in the subspecies of the European Western Scots pine - 1.9\%, slightly lower than this indicator in the forest-steppe subspecies (1.7\%). This indicator was significantly lower in the European Eastern pine variety - $1.1 \%$ and the Siberian subspecies $-1.0 \%$.

The obtained data on the composition of essential oil and the ratio of a number of components among subspecies and varieties of Scots pine (subspecies: Lapland, Siberian, foreststeppe, European; varieties: European western and eastern) will further select the most promising climatic ecotypes and subspecies for selection resistance to biotic and abiotic environmental factors, taking into account the growth and productivity of stands.

Information on the content of essential oil components in the needles of climatypes and subspecies of Scots pine makes it possible to expand knowledge in the field of plant resistance, their safety and growth, especially in the context of the outlined climate change.

Key words: component composition, extractives, monoterpenes, sesquiterpenes, diterpenes, geographical plantations, climatic ecotype.

* Supervisor - Doctor of Agricultural Sciences, Professor V. Yu. Yukhnovskyi. 
Introduction and analysis of recent publications. The integrated and rational use of plant resources involves the inclusion of the entire biomass of the plant in the production process. In particular, one of the main directions of the chemical processing of plant raw materials is the production of extractive substances. Among the extractives, it is customary to distinguish compounds that are directly involved in plant growth and compounds that are not involved in growth and development (Krasilnikova, 2004). The primary metabolites are carbohydrates, amino acids, fatty acids, chlorophylls, cytochromes, nucleotides, as well as compounds that act as intermediates in various metabolic reactions. In addition, plants contain a huge amount of substances that are not involved in the main metabolism. Such substances are usually called secondary metabolites or substances of secondary origin. Unlike primary metabolites present in all plant cells, secondary metabolites can be specific for one or several plant species (Kretovich, 1986; Crozier, 2006). Secondary metabolites include mainly low-molecular substances that are not part of the plant cell, contained in the intercellular space. This group of substances is extremely diverse in chemical composition. By their chemical nature, these substances are represented by terpenes and their derivatives, resin acids, lipids, fatty acids, phytosterols, polyphenols and tannins. Despite the assignment of these compounds to secondary metabolites, this is rather arbitrary, since many of these substances are the most important physiologically active compounds that play a primary role in the processes of respiration and photosynthesis. To date, about 20-30 thousand plant species have been studied for the presence of secondary metabolites, which make up only a little more than $10 \%$ of the entire flora of the Earth (Cheldt, 2011).
The variety of secondary metabolites also determines the variety of functions they perform (Kivanç \& Akgül, 1986; Teissedre \& Waterhouse, 2000; Mardarowicz, Wianowska, Dawidowicz \& Sawicki, 2004). But in general, we can say that secondary metabolites in plants perform primarily ecological functions. They protect plants from various pests and pathogens, participate in plant reproduction (determining the color and smell of flowers, fruits), and ensure the interaction of plants with each other and with other organisms in the ecosystem. In addition, this class of substances contributes to the formation of plant resistance to unfavorable factors (Babkin, 2017; Schmidt, 2005). Almost all of these substances also have biological activity, which makes them indispensable sources of raw materials in the production of pharmaceuticals, food, and perfumery products (Babkin, 2011; Plemenkov \& Tevs, 2014; Ponomoreva, Molochova \& Chochlov, 2015). Plant secondary compounds can be divided into three groups based on different biosynthetic pathways of their origin: alkaloids, phenolic compounds, and terpenoids (Plemenkov, 2001; Lovkova, 1981; Britton, 1986).

Terpenes are hydrocarbons formed from varying amounts of isoprene (C5H8). Without the participation of isoprenoids, processes such as the growth and development of plants and animals are impossible, since many plant hormones (gibberellins, abscisic acid, brassinosteroids) belong to this class of compounds. However, most of the isoprenoids known to date are substances of specialized (secondary) plant metabolism, which are involved in signaling processes and protection against phytopathogens. Obviously, the main role of isoprenoids specific for certain families, genera and species of plants (these are mainly mono-, sesqui-, di-, sisters- and triterpenoids) is reduced to protecting plants from various 
adverse environmental influences, including macro - and micro-pests. For example, resinous substances, rubber and gutta, heal wounds in the bark and wood of plants, protecting them from pests. Resins prevent animals from eating plants. Essential oils also help to attract pollinators. Many components of essential oils and other isoprenoids act as allelopathic agents. It should be noted that the reason for the formation of a huge number of various isoprenoids in plants still remains a mystery, the functions of many of them remain unclear. The process is carried out by absorbing the energy of sunlight, which is converted into the energy of chemical bonds, and is accompanied by the release of free oxygen. The resulting monosaccharides are converted in plants into cellulose, hemicelluloses, starch, lignin, fatty alcohols, acids, their esters, fats, amino acids, waxes, vitamins, essential oils, alkaloids.

In the literary sources the information is also given, which will be indicated in detail below that depending on the content of the components of the essential oil, the resistance of plants to abiotic and biotic environmental factors is determined.

In this regard, it is relevant to determine the content of essential oils in the needles of various climatic ecotypes of Scots pine growing in geographic forest cultures.

Numerous articles are devoted to the determination of the content of the components of Scots pine essential oil. In some of the works (Maksimov, 2004), the composition of the monoterpene fraction of the essential oil isolated from the needles of various subspecies of Scots pine in their habitat was studied.

According to Russian scientists from Forest Institute named after V.N. Sukachev (Kuzmin, 2019), more resistant climatypes of Scots pine are those with a higher ratio of $\alpha$-pinene to 3 -carene.
Finland researchers found out that northern climatypes have a higher content of $\alpha$-pinene in comparison with 3 -carene, and these climatypes are more stable in Finland (Manninen, Tarhanen, Vuorinen \& Kainulainen, 2002). Various specialized terpenoidogenic structures were found not only in needles, but also in the primary bark, secondary phloem and wood of the stem, roots and reproductive organs (Vasiliev, 1977).

Determination of the content of the share of essential oil in different parts of the tree indicates unequal concentration in the covered by needles shoots and trunk (Stepen, 1999).

A study of the seasonal dynamics of the release of essential oil in spruce (Esyakova \& Stepen, 2008), pine (Stepen, 1995; Petrenko, 1967) and fir (Lobanov \& Stepen, 2004) shows that there are two peaks in the oil content in needles: spring - in May and autumn - in September.

During the transition to the dormant state of trees in the plantation, the essential oil is enriched with oxygen-containing compounds and sesquiterpenes and reaches a maximum in the month of December. The specificity was also noted in the study of pine forests in Ukraine (Poltavchenko \& Rudakov, 1973).

The aim of the research is to analyze the content of terpenes in the needles of trees of climatic ecotypes of Scots pine growing in geographic forest cultures and to reveal the differences in the level of essential oils.

Materials and methods of research. The object of the research is 17 Scots pine climatypes growing in geographical plantations on the territory of the Negorelsk Educational and Experimental Forestry Enterprise of the Minsk region in Belarus. Scots pine geographic plantations were created in 1959 by V. Mishnev and E. Mantsevich in collaboration with 
the Central Control Station of Forest Seeds and the Belarusian Control Station of Forest Seeds on an area of 8.7 hectares. The seeds were obtained from 200 locations in the former Soviet Union. However, most of them were excluded due to typological heterogeneity. As a result, 65 seed samples were selected from the plantations of the group of forest types of the green moss forest, which were sown in April 1958 in the nursery of the Negorelsk Experimental Forestry. The soil on the nursery is coherent sand in terms of texture. To obtain the same seedling density in one row, the same number of viable seeds per 1 long $\mathrm{m}$ was sown. After sowing, the ridges were covered with moss. Until mid-July, seedlings were shaded with sieve shields. The seedlings were taken care of, which consisted of weeding and loosening the soil three times.

The area for geographic plantations was set aside in the quarter 15 the forest cultivation area was a clearcut of 1958 , with the correct configuration, stretched from north to south. In the fall, the cutting area was grubbed and leveled with a bulldozer, then plowed to a depth of 25 $\mathrm{cm}$. In April 1959, the area was re-leveled with a bulldozer and harrowed with disc harrows in two tracks.

The final leveling of the area was carried out manually with gathering and burning of the roots before planting. The spatial distribution of plantations was made according to the principle of allocation of large climatic regions. These areas are located on the site in the direction from north to south, and they are grouped according to the greatest geographic difference from west to east. Each administrative region is represented by a plot of planting with an area of 0.1 hectares. These sections are bounded on all sides by a 2-meter road and poles are set. On the western side, a 4-meter road adjoins the site. The work Kruk et al. (2019) provides information that this object as geographic forest plantations was the source material for obtaining the Scots pine Negorelskaya variety for the first time in Belarus, which is characterized by intensive growth in height and resistance to fusarium.

For a more convenient analysis of the content of essential oil components in needles, all studied climatypes of Scots pine in geographical plantations are divided into subspecies (races, varieties) in accordance with the classification by Pravdin (1964) (subspecies Lapland, European, Siberian, steppe, hooked) with some modification. The hooked subspecies that grows in the Crimea and the Caucasus is not represented in our experience. Since the steppe subspecies in geographical plantations completely disappeared at the age of 5 (Kustanai, Kokchetav, Akmola, Pavlodar climatypes of Kazakhstan), we additionally introduced the forest-steppe group of climatypes: Belgorod, Kursk, Volgograd, Khmelnitsky, Poltava, Rostov. We also subdivided the European subspecies into two varieties - European western (Vologda, Estonian, Latvian, Vitebsk, Minsk and Grodno) and European eastern (Ulyanovsk and Bashkir).

Method of selection of woody greenery. The woody greenery of Scots pine climatypes in geographic plantations were selected from 17 plots with 20-25 trees in each of them, taken by the randomization method, in the crown of which branches were cut evenly from four sides. Woody greens were taken in the month of February. According to the literature, the release of essential oil reaches its maximum value and its composition stabilizes in the winter months (Stepen, 1995).

Metod of selection of middle sample. The needles were separated from the cut 
branches of woody greens trees without dividing them by age, and an initial sample of the material under study was obtained. The formation of the middle sample from the original was carried out by quartering. The original sample was poured onto a smooth surface and leveled in the form of a square, and then simultaneously from two opposite sides it was poured into the middle so that a roller was obtained. After that, we grabbed the needles from the ends of the roller and also poured them into the middle. The needles were again smoothed over the area of the square and again poured into the middle. Stirring was repeated in this manner three times. After mixing, the original sample was again smoothed with a thin layer and divided into four triangles. Two opposite triangles of the needles were removed, and the two remaining ones were connected, mixed and again divided in the indicated manner until the mass of one triangle was approximately five times the weight of the sample. From one triangle, a weighed portion was taken for chemical analysis (isolation of essential oil), and from the opposite triangle, a weighed portion was taken to determine the moisture content of the sample (Deruma, 1983).

Method for the extraction of essential oil from needles. Most of the components of essential oils have a boiling point of 150 to $300^{\circ} \mathrm{C}$ and higher, however, all the substances that make up their composition are distilled with water vapor. The hydro distillation method is based on the ability of oils to be distilled with water vapor and on the determination of the amount of oil that is released from a plant sample (Pleshkov, 1985). The 150$250 \mathrm{~g}$ of raw material crushed to a size of 4-7 mm with known moisture content was placed in a flask with a capacity of $500 \mathrm{~cm}^{3}$, and it was poured with distilled water so that the water surface covered the plant material. The flask was placed in a heating mantle, and then a nozzle for collecting essential oils and a reflux condenser were attached. After the beginning of boiling, the resulting vapor, carrying with it the essential oil, entered the refrigerator, where it condensed into a liquid consisting of water and small drops of essential oil. The condensed mixture passed into the receiver to collect the essential oil. The intensity of boiling was selected in such a way that 2-3 drops per second flowed out of the refrigerator. Otherwise, the refrigerator could be "flooded" and ejection. Water, as a heavier liquid, settled to the bottom of the receiver and poured back into the flask, and the essential oil floated to the surface, where it slowly accumulated. The process of hydrodistillation in the boiling stage lasted at least 4 hours. During this time, about $80 \%$ of the essential oil contained in the plant was distilled off. After the end of the distillation process, the flask was cooled and the device was disassembled (Figure 1).

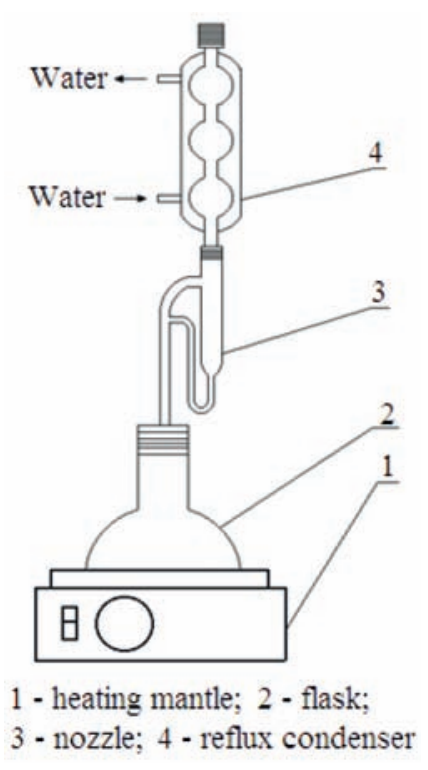

Fig. 1. Installation for the extraction of essential oil 
The essential oil was located in the collector in the form of a thin layer (yellowish) above the water surface. The selection of essential oil was carried out using a syringe with a long needle. The essential oil was carefully poured using a syringe into a pre-weighed small tightly closing bottle, the name of the essential oil and the date of extraction were signed.

The calculation of the essential oil content in the needles was carried out on an absolutely dry weight of plant material. The calculation of the results in mass percent was carried out according to the formula 1 :

$$
C=\frac{m}{G} \cdot 100 \%,
$$

where $C$ - essential oil content, \% (mass); $m$ - the mass of the essential oil after distillation, g; $G$ - the mass of an absolutely dry sample of needles, g.

The resulting essential oil was dried with anhydrous sodium sulfate and then used to determine its physical, physicochemical parameters, as well as for chemical research.

Qualitative and quantitative analysis of Scots pine needles essential oil was carried out by gas-liquid chromatography without preliminary fractionation on chromatograph "Kristall 5000.1". To separate the components, a capillary column $0.25 \mathrm{~mm}$ in diameter and $60 \mathrm{~m}$ long with a deposited phase of $100 \%$ dimethylsiloxane was used. Nitrogen was used as a carrier gas. The air: nitrogen: hydrogen flow rate ratio was 10: 1: 1 . The nitrogen flow rate through the column was $20 \mathrm{ml} / \mathrm{min}$.

The conditions for chromatographic analysis are as follows: isothermal mode at $70^{\circ} \mathrm{C}$ for $20 \mathrm{~min}$, then a programmed temperature rise at a rate of $2^{\circ} \mathrm{C} / \mathrm{min}$ to $150^{\circ} \mathrm{C}$ with holding at the final temperature for $40 \mathrm{~min}$. Evaporator temperature $-250^{\circ} \mathrm{C}$. The analyzed sample with a volume of $0.2 \mu \mathrm{L}$ was introduced with a microsyringe into the dispenser-evaporator.

The identification of individual components was carried out using reference compounds, as well as on the basis of the known literature data on the retention indices of individual compounds (Cheftman, 1986). The quantitative content of the components was calculated by the method of internal normalization according to the peak areas. Statistical analysis was performed in accordance with the methods described in Ostakin et al. (1989), Pen (1982) and Kolesnikov (2003). To determine the required sample size when performing the research, the admissible error value $\Delta \mathrm{x}$ was taken equal to $5 \%$ of the average value of the indicator at a confidence level of $\alpha=95 \%$. After the experiment, the variance $\mathrm{S} 2$ and the standard deviation $\mathrm{S}$ were calculated. Next, the ratio $\Delta \mathrm{x} / \mathrm{S}$ was found, and the sample size was determined from the corresponding table (Pen $\&$ Mencher, 1973). The results of each series of parallel experiments were subjected to statistical processing in order to find gross errors ("blunders") using the Student's test (Ostakin et al., 1989). In this case, the dubious result was excluded from the sample, and the remaining data were used to calculate the arithmetic mean and the estimate of the reproducibility variance.

Results of the research and their discussion. The obtained data on the physicochemical parameters of Scots pine essential oil of various geographical origin indicate that among the studied climatypes, grouped into subspecies, there are differences in the mass fraction of essential oil in terms of absolutely dry weight, relative density and refractive index at $\mathrm{t}=20^{\circ} \mathrm{C}$ (Table 1).

The highest yield of essential oil is observed in the subspecies of the Euro- 


\section{Changes in the physicochemical parameters of Scots pine essential oil of various geographical origin}

\begin{tabular}{|c|c|c|c|}
\hline \multirow{2}{*}{$\begin{array}{l}\text { Name of the climatype } \\
\text { (subspecies, varieties) } \\
\text { of Scots pine }\end{array}$} & \multicolumn{3}{|c|}{ Physicochemical parameters of essential oil of Scots pine climatypes } \\
\hline & $\begin{array}{c}\text { mass fraction of essential } \\
\text { oil, in terms of absolutely } \\
\text { dry weight, } \%\end{array}$ & $\begin{array}{l}\text { relative density, } \\
\mathrm{g} / \mathrm{cm}^{3}\end{array}$ & $\begin{array}{c}\text { refractive index at } \\
t=20^{\circ} \mathrm{C}\end{array}$ \\
\hline \multicolumn{4}{|c|}{ Scots pine subspecies Lapland } \\
\hline Leningrad, Arkhangelsk & $\begin{array}{l}1,7 \pm 0,1 \\
1,9 \pm 0,1\end{array}$ & $\begin{array}{l}0,8639 \pm 0,005 \\
0,8632 \pm 0,005\end{array}$ & $\begin{array}{l}1,4841 \pm 0,001 \\
1,4836 \pm 0,001\end{array}$ \\
\hline By subspecies Lapland & $1,8 \pm 0,1$ & $0,8635 \pm 0,005$ & $1,4838 \pm 0,001$ \\
\hline \multicolumn{4}{|c|}{ Scots pine variety European western } \\
\hline $\begin{array}{l}\text { Vologda, } \\
\text { Estonian, } \\
\text { Latvian, } \\
\text { Vitebsk, } \\
\text { Minsk, } \\
\text { Grodno }\end{array}$ & $\begin{array}{l}1,4 \pm 0,1 \\
1,8 \pm 0,1 \\
1,9 \pm 0,1 \\
2,0 \pm 0,1 \\
2,0 \pm 0,1 \\
2,1 \pm 0,1\end{array}$ & $\begin{array}{l}0,8639 \pm 0,005 \\
0,8638 \pm 0,005 \\
0,8639 \pm 0,005 \\
0,8632 \pm 0,005 \\
0,8633 \pm 0,005 \\
0,8628 \pm 0,005\end{array}$ & $\begin{array}{l}1,4840 \pm 0,001 \\
1,4844 \pm 0,001 \\
1,4850 \pm 0,001 \\
1,4849 \pm 0,001 \\
1,4850 \pm 0,001 \\
1,4849 \pm 0,001\end{array}$ \\
\hline $\begin{array}{l}\text { By variety European } \\
\text { Western }\end{array}$ & $1,9 \pm 0,1$ & $0,8635 \pm 0,005$ & $1,4847 \pm 0,001$ \\
\hline \multicolumn{4}{|c|}{ Scots pine variety European oriental } \\
\hline $\begin{array}{l}\text { Ulyanovsk, } \\
\text { Bashkir }\end{array}$ & $\begin{array}{l}1,0 \pm 0,1 \\
1,1 \pm 0,1\end{array}$ & $\begin{array}{l}0,8638 \pm 0,005 \\
0,8639 \pm 0,005\end{array}$ & $\begin{array}{l}1,4840 \pm 0,001 \\
1,4842 \pm 0,001\end{array}$ \\
\hline $\begin{array}{l}\text { By variety } \\
\text { European oriental }\end{array}$ & $1,1 \pm 0,1$ & $0,8639 \pm 0,005$ & $1,4841 \pm 0,001$ \\
\hline By subspecies European & $1,7 \pm 0,1$ & $0,8636 \pm 0,005$ & $1,4846 \pm 0,001$ \\
\hline \multicolumn{4}{|c|}{ Scots pine subspecies forest-steppe } \\
\hline $\begin{array}{l}\text { Belgorodsky, } \\
\text { Kursk, } \\
\text { Volgograd, } \\
\text { Khmelnitsky, } \\
\text { Poltava, } \\
\text { Rostov }\end{array}$ & $\begin{array}{l}1,6 \pm 0,1 \\
1,8 \pm 0,1 \\
1,6 \pm 0,1 \\
1,7 \pm 0,1 \\
1,8 \pm 0,1 \\
1,7 \pm 0,1\end{array}$ & $\begin{array}{l}0,8634 \pm 0,005 \\
0,8633 \pm 0,005 \\
0,8628 \pm 0,005 \\
0,8639 \pm 0,005 \\
0,8635 \pm 0,005 \\
0,8633 \pm 0,005\end{array}$ & $\begin{array}{l}1,4838 \pm 0,001 \\
1,4840 \pm 0,001 \\
1,4846 \pm 0,001 \\
1,4846 \pm 0,001 \\
1,4840 \pm 0,001 \\
1,4840 \pm 0,001\end{array}$ \\
\hline $\begin{array}{l}\text { By subspecies } \\
\text { forest-steppe }\end{array}$ & $1,7 \pm 0,1$ & $0,8634 \pm 0,005$ & $1,4842 \pm 0,001$ \\
\hline \multicolumn{4}{|c|}{ Scots pine Siberian subspecies } \\
\hline Tomsk & $1,0 \pm 0,1$ & $0,8639 \pm 0,005$ & $1,4838 \pm 0,001$ \\
\hline By subspecies Siberian & $1,0 \pm 0,1$ & $0,8639 \pm 0,005$ & $1,4838 \pm 0,001$ \\
\hline
\end{tabular}

pean Western Scots pine $-1.9 \%$, slightly lower than this indicator in the foreststeppe subspecies $(1.7 \%)$. This indicator was significantly lower in the European Eastern pine variety $-1.1 \%$ and the $\mathrm{Si}$ berian subspecies $-1.0 \%$. It is noted that an essential oil content of $1 \%$ is typical for pines growing in extreme conditions of an urbanized environment (Lamotkin, Hil, Romanyuk \& Skakovskiy, 2019).

The relative density of the essential oil of the studied subspecies of Scots pine varies within insignificant limits from 0.8634 to $0.8639 \mathrm{~g} / \mathrm{cm}^{3}$ (minimum in Grodno and Volgograd climatypes $0.8628 \mathrm{~g} / \mathrm{cm}^{3}$ each and maximum - in Leningrad, Vologda, Latvian, Khmelnitsky, Bashkir and Tomsk climatypes $0.8639 \mathrm{~g} / \mathrm{cm}^{3}$ each). In terms of the refractive index, the variation ranges from 1.4838 (subspecies Lapland and Siberian) to 1.4847 (European Western Scots pine).

The results of determining the content of the main components of essential oil 
2. The content of the main components in the essential oil of various climatypes of Scots pine growing in 61-year-old geographical plantations

\begin{tabular}{|c|c|c|c|c|c|c|c|c|c|c|c|}
\hline \multirow[b]{2}{*}{$\begin{array}{l}\text { Name of the climatype } \\
\text { (subspecies, varieties) } \\
\text { of Scots pine }\end{array}$} & \multicolumn{11}{|c|}{ The main components of the essential oil, $\%$} \\
\hline & 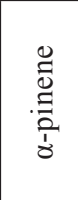 & 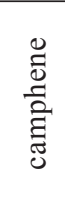 & 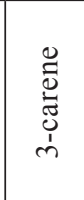 & $\begin{array}{l}\mathscr{\Xi} \\
\stackrel{\Xi}{0} \\
\Xi\end{array}$ & 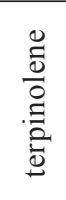 & 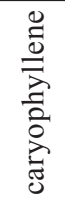 & 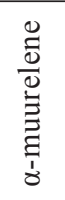 & 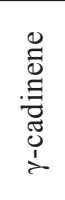 & 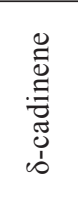 & 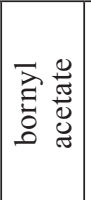 & 宽 \\
\hline \multicolumn{12}{|c|}{ Scots pine subspecies Lapland } \\
\hline Leningrad, Arkhangelsk & \begin{tabular}{|l|}
30,2 \\
43,3
\end{tabular} & $\begin{array}{l}3,6 \\
3,2\end{array}$ & $\begin{array}{c}17,2 \\
5,9\end{array}$ & $\begin{array}{l}2,4 \\
0,9\end{array}$ & $\begin{array}{l}3,0 \\
0,6\end{array}$ & $\begin{array}{l}1,8 \\
5,0\end{array}$ & $\begin{array}{l}4,6 \\
4,5\end{array}$ & $\begin{array}{l}2,4 \\
5,1\end{array}$ & $\begin{array}{l}6,4 \\
8,1\end{array}$ & $\begin{array}{l}2,2 \\
3,7\end{array}$ & $\begin{array}{l}74,0 \\
80,2\end{array}$ \\
\hline By subspecies Lapland & 36,8 & 3,4 & 11,6 & 1,7 & 1,8 & 3,4 & 4,5 & 3,8 & 7,2 & 2,9 & 77,1 \\
\hline \multicolumn{12}{|c|}{ Scots pine variety European western } \\
\hline $\begin{array}{l}\text { Vologda, } \\
\text { Estonian, } \\
\text { Latvian, } \\
\text { Vitebsk, } \\
\text { Minsk, } \\
\text { Grodno } \\
\end{array}$ & $\begin{array}{l}39,0 \\
31,2 \\
17,1 \\
18,0 \\
20,6 \\
17,9 \\
\end{array}$ & $\begin{array}{l}5,1 \\
2,8 \\
2,8 \\
2,6 \\
3,2 \\
3,5 \\
\end{array}$ & \begin{tabular}{|l|}
13,7 \\
13,5 \\
24,2 \\
23,2 \\
24,0 \\
24,1 \\
\end{tabular} & $\begin{array}{l}2,0 \\
1,5 \\
1,1 \\
2,1 \\
2,1 \\
2,4 \\
\end{array}$ & $\begin{array}{l}1,5 \\
1,6 \\
2,6 \\
2,1 \\
2,6 \\
4,0\end{array}$ & $\begin{array}{l}6,0 \\
3,0 \\
6,2 \\
6,7 \\
7,3 \\
5,2 \\
\end{array}$ & $\begin{array}{l}3,0 \\
4,1 \\
6,5 \\
5,5 \\
4,3 \\
4,4 \\
\end{array}$ & $\begin{array}{l}, 3 \\
4,6 \\
3,2 \\
4,7 \\
4,2 \\
3,6 \\
\end{array}$ & $\begin{array}{l}3,1 \\
7,9 \\
7,3 \\
8,2 \\
6,9 \\
7,4 \\
\end{array}$ & $\begin{array}{l}0,8 \\
1,5 \\
1,9 \\
1,8 \\
1,2 \\
2,0 \\
\end{array}$ & $\begin{array}{l}75,6 \\
71,6 \\
72,8 \\
75,0 \\
76,4 \\
74,5 \\
\end{array}$ \\
\hline $\begin{array}{l}\text { By variety European } \\
\text { Western }\end{array}$ & 24,0 & 3,3 & 20,5 & 1,9 & 2,4 & 5,7 & 4,6 & 3,6 & 6,8 & 1,5 & 74,3 \\
\hline \multicolumn{12}{|c|}{ Scots pine variety European oriental } \\
\hline $\begin{array}{l}\text { Ulyanovsk, } \\
\text { Bashkir }\end{array}$ & \begin{tabular}{|l}
20,3 \\
16,8 \\
\end{tabular} & $\begin{array}{l}1,9 \\
2,2\end{array}$ & $\begin{array}{l}8,8 \\
9,3\end{array}$ & $\begin{array}{l}2,5 \\
3,0\end{array}$ & $\begin{array}{l}1,5 \\
1,1 \\
\end{array}$ & $\begin{array}{l}3,7 \\
6,8 \\
\end{array}$ & $\begin{array}{l}8,2 \\
5,4\end{array}$ & $\begin{array}{l}5,7 \\
4,8 \\
\end{array}$ & $\begin{array}{c}5,9 \\
10,7 \\
\end{array}$ & $\begin{array}{l}0,8 \\
1,0\end{array}$ & $\begin{array}{l}59,3 \\
61,1 \\
\end{array}$ \\
\hline $\begin{array}{l}\text { By variety } \\
\text { European oriental }\end{array}$ & 18,6 & 2,1 & 9,1 & 2,8 & 1,3 & 5,3 & 6,8 & 5,3 & 8,3 & 0,9 & 60,2 \\
\hline By subspecies European & 22,6 & 3,0 & 17,6 & 2,1 & 2,1 & 5,6 & 5,2 & 4,0 & 7,2 & 1,4 & 70,8 \\
\hline \multicolumn{12}{|c|}{ Scots pine subspecies forest-steppe } \\
\hline $\begin{array}{l}\text { Belgorodsky, } \\
\text { Kursk, } \\
\text { Volgograd, } \\
\text { Khmelnitsky, } \\
\text { Poltava, } \\
\text { Rostov }\end{array}$ & \begin{tabular}{|l|}
21,9 \\
21,2 \\
25,5 \\
15,2 \\
16,9 \\
27,0
\end{tabular} & $\begin{array}{l}1,8 \\
1,9 \\
3,8 \\
2,3 \\
1,5 \\
2,4\end{array}$ & \begin{tabular}{|c|}
8,2 \\
9,3 \\
16,9 \\
13,7 \\
4,8 \\
14,5 \\
\end{tabular} & $\begin{array}{l}1,1 \\
1,4 \\
1,2 \\
1,7 \\
1,1 \\
2,4\end{array}$ & $\begin{array}{l}1,3 \\
1,3 \\
2,5 \\
1,9 \\
0,7 \\
2,1\end{array}$ & $\begin{array}{c}5,3 \\
4,5 \\
13,4 \\
8,8 \\
6,6 \\
5,7\end{array}$ & $\begin{array}{l}5,1 \\
3,1 \\
2,0 \\
9,7 \\
7,6 \\
3,7\end{array}$ & $\begin{array}{l}7,0 \\
7,1 \\
1,9 \\
6,9 \\
8,1 \\
4,9\end{array}$ & $\begin{array}{c}12,6 \\
13,1 \\
5,0 \\
10,9 \\
17,4 \\
9,1 \\
\end{array}$ & \begin{tabular}{l|}
1,3 \\
0,8 \\
2,3 \\
1,7 \\
1,5 \\
1,6 \\
\end{tabular} & $\begin{array}{l}65,7 \\
63,8 \\
74,4 \\
72,7 \\
66,1 \\
73,2\end{array}$ \\
\hline $\begin{array}{l}\text { By subspecies } \\
\text { forest-steppe }\end{array}$ & 21,3 & 2,3 & 11,2 & 1,5 & 1,6 & 7,4 & 5,2 & 6,0 & 11,4 & 1,5 & 69,3 \\
\hline \multicolumn{12}{|c|}{ Scots pine Siberian subspecies } \\
\hline Tomsk & 21,0 & 2,5 & 8,7 & 2,2 & 1,5 & 3,6 & 5,0 & 5,9 & 9,6 & 1,5 & 61,5 \\
\hline By subspecies Siberian & 21,0 & 2,5 & 8,7 & 2,2 & 1,5 & 3,6 & 5,0 & 5,9 & 9,6 & 1,5 & 61,5 \\
\hline
\end{tabular}

in the needles of various climatypes of Scots pine are presented in Table 2, the group composition of monoterpenes - in Table 3, the group composition of sesquiterpenes - in Table 4.

It should be mentioned that the lowest content among the group of monoterpenes, sesquiterpenes and the oxygencontaining group was noted in the latter, while the proportion of bornyl acetate in the essential oil does not exceed $3 \%-$ from $0.9 \%$ in the European oriental variety to $2.9 \%$ in the Lapland pine.

It was found that the largest share of the identified components of essential oil was in the variant of Scots pine of the Lapland subspecies - 77.1\%. In the variety of Western European Scots pine, the share of recognized components was slightly lower and amounted to $74.3 \%$, 


\section{Composition of essential oil monoterpenes in various subspecies of Scots pine in 61-year-old geographical forest plantations}

\begin{tabular}{|c|c|c|c|c|c|c|c|c|}
\hline \multirow[b]{2}{*}{$\begin{array}{c}\text { Name of the climatype } \\
\text { (subspecies, varieties) } \\
\text { of Scots pine }\end{array}$} & \multicolumn{2}{|c|}{ Geographical coordinates } & \multicolumn{6}{|c|}{ Essential oil group - monoterpenes } \\
\hline & 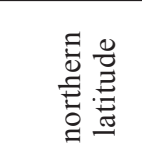 & 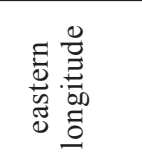 & 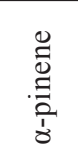 & 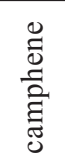 & 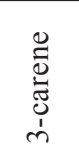 & 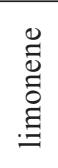 & $\begin{array}{l}0 \\
\stackrel{0}{0} \\
0 \\
.0 \\
\stackrel{0}{0}\end{array}$ & $\stackrel{\pi}{0}$ \\
\hline \multicolumn{9}{|l|}{ Scots pine subspecies Lapland } \\
\hline $\begin{array}{l}\text { Leningrad, } \\
\text { Arkhangelsk }\end{array}$ & $\begin{array}{l}61 \\
62\end{array}$ & $\begin{array}{l}34 \\
43\end{array}$ & $\begin{array}{l}45,8 \\
74,0\end{array}$ & $\begin{array}{l}5,5 \\
5,4\end{array}$ & $\begin{array}{l}26,1 \\
10,1\end{array}$ & $\begin{array}{l}3,7 \\
1,5\end{array}$ & $\begin{array}{l}4,5 \\
1,0\end{array}$ & $\begin{array}{l}66,0 \\
58,5\end{array}$ \\
\hline By subspecies Lapland & $61-62$ & $34-43$ & 59,9 & 5,5 & 18,1 & 2,6 & 2,8 & 62,3 \\
\hline \multicolumn{9}{|c|}{ Scots pine variety European western } \\
\hline $\begin{array}{l}\text { Vologda, } \\
\text { Estonian, } \\
\text { Latvian, } \\
\text { Vitebsk, } \\
\text { Minsk, } \\
\text { Grodno }\end{array}$ & $\begin{array}{l}59 \\
58 \\
57 \\
55 \\
54 \\
53\end{array}$ & $\begin{array}{l}40 \\
27 \\
22 \\
29 \\
27 \\
24\end{array}$ & $\begin{array}{l}53,4 \\
51,6 \\
30,9 \\
31,1 \\
33,0 \\
29,5\end{array}$ & $\begin{array}{l}7,0 \\
4,6 \\
5,1 \\
4,5 \\
5,1 \\
5,7\end{array}$ & $\begin{array}{l}18,8 \\
22,3 \\
43,6 \\
40,0 \\
38,4 \\
39,7\end{array}$ & $\begin{array}{l}2,7 \\
2,5 \\
1,9 \\
3,6 \\
3,3 \\
4,0\end{array}$ & $\begin{array}{l}2,1 \\
2,7 \\
4,6 \\
3,6 \\
4,2 \\
6,5 \\
\end{array}$ & $\begin{array}{l}73,1 \\
60,4 \\
55,5 \\
58,0 \\
62,5 \\
60,8\end{array}$ \\
\hline By variety European Western & $53-59$ & $22-40$ & 38,3 & 5,3 & 33,8 & 3,0 & 4,0 & 61,7 \\
\hline \multicolumn{9}{|c|}{ Scots pine variety European oriental } \\
\hline $\begin{array}{l}\text { Ulyanovsk, } \\
\text { Bashkir }\end{array}$ & $\begin{array}{l}54 \\
54\end{array}$ & $\begin{array}{l}48 \\
58\end{array}$ & $\begin{array}{l}46,3 \\
37,7\end{array}$ & $\begin{array}{l}4,4 \\
5,0\end{array}$ & $\begin{array}{l}20,1 \\
21,0\end{array}$ & $\begin{array}{l}5,6 \\
6,7\end{array}$ & $\begin{array}{l}3,4 \\
2,4\end{array}$ & $\begin{array}{l}43,8 \\
44,5\end{array}$ \\
\hline By variety European oriental & 54 & $48-58$ & 42,0 & 4,7 & 20,6 & 6,2 & 2,9 & 44,2 \\
\hline By subspecies European & $53-59$ & $22-58$ & 39,2 & 5,2 & 30,5 & 3,8 & 3,7 & 57,3 \\
\hline \multicolumn{9}{|c|}{ Scots pine subspecies forest-steppe } \\
\hline $\begin{array}{l}\text { Belgorodsky, } \\
\text { Kursk, } \\
\text { Volgograd, } \\
\text { Khmelnitsky, } \\
\text { Poltava, } \\
\text { Rostov }\end{array}$ & $\begin{array}{l}51 \\
51 \\
51 \\
50 \\
49 \\
47\end{array}$ & $\begin{array}{l}38 \\
34 \\
42 \\
27 \\
33 \\
40\end{array}$ & $\begin{array}{l}57,4 \\
52,3 \\
42,5 \\
36,1 \\
60,4 \\
48,5\end{array}$ & $\begin{array}{l}4,8 \\
4,7 \\
6,3 \\
5,4 \\
5,2 \\
4,4\end{array}$ & $\begin{array}{l}21,6 \\
22,9 \\
28,1 \\
32,4 \\
17,1 \\
26,0\end{array}$ & $\begin{array}{l}2,8 \\
3,5 \\
2,0 \\
4,0 \\
3,9 \\
4,3\end{array}$ & $\begin{array}{l}3,3 \\
3,1 \\
4,2 \\
4,4 \\
2,5 \\
3,8\end{array}$ & $\begin{array}{l}38,1 \\
40,6 \\
60,0 \\
42,2 \\
27,9 \\
55,6\end{array}$ \\
\hline $\begin{array}{l}\text { By subspecies } \\
\text { forest-steppe }\end{array}$ & $47-51$ & $27-40$ & 49,5 & 5,1 & 24,7 & 3,4 & 3,6 & 44,1 \\
\hline \multicolumn{9}{|c|}{ Scots pine Siberian subspecies } \\
\hline Tomsk & 57 & 85 & 47,6 & 5,7 & 19,7 & 4,9 & 3,3 & 44,1 \\
\hline By subspecies Siberian & 57 & 85 & 47,6 & 5,7 & 19,7 & 4,9 & 3,3 & 44,1 \\
\hline
\end{tabular}

in the forest-steppe subspecies $-69.3 \%$. This indicator turned out to be significantly lower in the variants of the Siberian subspecies and the variety of the European Eastern $-61.5 \%$ and $60.2 \%$, respectively.

In terms of the content of $\alpha$-pinene, a component of monoterpenes, the subspecies of Lapland pine has the highest share $-36.8 \%$. This indicator is at the level of $21.0-24.0 \%$ in other variants of subspecies and varieties.
In terms of the content of 3-carene, an inverse relationship is observed - the least of this component is in the Siberian, forest-steppe and Lapland pine $-8.7 \%$, $11.2 \%$ and $11.6 \%$, respectively. The maximum is observed in the European western variety $-20.5 \%$. In the Lapland pine, the ratio of these components reaches more than $3: 1$. This ratio is achieved in the Siberian pine and the European eastern variety at the level of 2-3:1. A slightly lower ratio of $2: 1$ was noted in the 
С. В. Ребко, Л. Ф. Поплавська, С. А. Ламоткін,

І. В. Кімейчук, В. М. Хрик, В. Ю. Юхновський

4. Composition of essential oil sesquiterpenes in various subspecies of Scots pine in 61-year-old geographical forest plantations

\begin{tabular}{|c|c|c|c|c|c|c|c|}
\hline \multirow[b]{2}{*}{$\begin{array}{c}\text { Name of the climatype } \\
\text { (subspecies, varieties) } \\
\text { of Scots pine }\end{array}$} & \multicolumn{2}{|c|}{ Geographical coordinates } & \multicolumn{5}{|c|}{ Essential oil group - sesquiterpenes } \\
\hline & 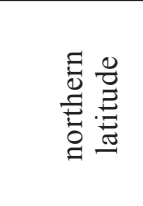 & 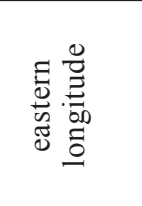 &  & 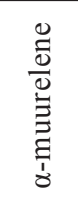 & 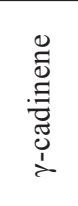 & 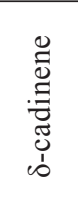 & 苛 \\
\hline \multicolumn{8}{|c|}{ Scots pine subspecies Lapland } \\
\hline $\begin{array}{l}\text { Leningrad, } \\
\text { Arkhangelsk }\end{array}$ & $\begin{array}{l}61 \\
62\end{array}$ & $\begin{array}{l}34 \\
43\end{array}$ & $\begin{array}{c}5,9 \\
13,6\end{array}$ & $\begin{array}{l}15,6 \\
12,3\end{array}$ & $\begin{array}{c}8,2 \\
13,9\end{array}$ & $\begin{array}{l}21,6 \\
22,1\end{array}$ & $\begin{array}{l}29,8 \\
36,6\end{array}$ \\
\hline By subspecies Lapland & $61-62$ & $34-43$ & 9,8 & 13,9 & 11,1 & 21,9 & 33,2 \\
\hline \multicolumn{8}{|c|}{ Scots pine variety European western } \\
\hline $\begin{array}{l}\text { Vologda, } \\
\text { Estonian, } \\
\text { Latvian, } \\
\text { Vitebsk, } \\
\text { Minsk, } \\
\text { Grodno }\end{array}$ & $\begin{array}{l}59 \\
58 \\
57 \\
55 \\
54 \\
53\end{array}$ & $\begin{array}{l}40 \\
27 \\
22 \\
29 \\
27 \\
24\end{array}$ & $\begin{array}{c}24,2 \\
8,5 \\
15,2 \\
17,7 \\
21,5 \\
14,6\end{array}$ & $\begin{array}{l}12,2 \\
11,8 \\
15,9 \\
14,5 \\
12,7 \\
12,4\end{array}$ & $\begin{array}{c}5,1 \\
13,3 \\
7,9 \\
12,5 \\
12,3 \\
10,1\end{array}$ & $\begin{array}{l}12,6 \\
22,6 \\
18,1 \\
21,6 \\
20,1 \\
20,8\end{array}$ & $\begin{array}{l}24,7 \\
34,8 \\
40,6 \\
37,9 \\
34,1 \\
35,4\end{array}$ \\
\hline $\begin{array}{l}\text { By variety European } \\
\text { Western }\end{array}$ & $53-59$ & $22-40$ & 17,0 & 13,3 & 10,2 & 19,3 & 34,6 \\
\hline \multicolumn{8}{|c|}{ Scots pine variety European oriental } \\
\hline $\begin{array}{l}\text { Ulyanovsk, } \\
\text { Bashkir }\end{array}$ & $\begin{array}{l}54 \\
54 \\
\end{array}$ & $\begin{array}{l}48 \\
58\end{array}$ & $\begin{array}{c}6,9 \\
12,8 \\
\end{array}$ & $\begin{array}{l}15,2 \\
10,2 \\
\end{array}$ & $\begin{array}{c}10,6 \\
9,0\end{array}$ & $\begin{array}{l}10,8 \\
20,2 \\
\end{array}$ & $\begin{array}{l}54,2 \\
53,1\end{array}$ \\
\hline $\begin{array}{l}\text { By variety } \\
\text { European oriental }\end{array}$ & 54 & $48-58$ & 9,9 & 12,7 & 9,8 & 15,5 & 53,7 \\
\hline By subspecies European & $53-59$ & $22-58$ & 15,2 & 13,1 & 10,1 & 18,4 & 39,4 \\
\hline \multicolumn{8}{|c|}{ Scots pine subspecies forest-steppe } \\
\hline $\begin{array}{l}\text { Belgorodsky, } \\
\text { Kursk, } \\
\text { Volgograd, } \\
\text { Khmelnitsky, } \\
\text { Poltava, } \\
\text { Rostov }\end{array}$ & $\begin{array}{l}51 \\
51 \\
51 \\
50 \\
49 \\
47\end{array}$ & $\begin{array}{l}38 \\
34 \\
42 \\
27 \\
33 \\
40\end{array}$ & $\begin{array}{c}9,0 \\
8,0 \\
37,4 \\
16,1 \\
9,5 \\
13,9 \\
\end{array}$ & $\begin{array}{c}8,6 \\
5,5 \\
5,6 \\
17,7 \\
10,9 \\
9,0 \\
\end{array}$ & $\begin{array}{c}11,9 \\
12,5 \\
5,3 \\
12,5 \\
11,7 \\
12,1\end{array}$ & $\begin{array}{l}21,4 \\
23,1 \\
13,9 \\
19,9 \\
25,1 \\
22,3\end{array}$ & $\begin{array}{l}59,1 \\
56,8 \\
35,8 \\
54,8 \\
69,4 \\
40,7\end{array}$ \\
\hline By subspecies forest-steppe & $47-51$ & $27-40$ & 15,7 & 9,6 & 11,0 & 21,0 & 52,8 \\
\hline \multicolumn{8}{|c|}{ Scots pine Siberian subspecies } \\
\hline Tomsk & 57 & 85 & 8,4 & 11,6 & 13,7 & 22,1 & 43,4 \\
\hline By subspecies Siberian & 57 & 85 & 8,4 & 11,6 & 13,7 & 22,1 & 43,4 \\
\hline
\end{tabular}

forest-steppe subspecies and the European western variety.

A more detailed analysis of the component composition of monoterpenes is presented in table 3 . The proportion of monoterpenes in the total amount of essential oils ranges from $44.1 \%$ (subspecies Siberian and forest-steppe) to $62.3 \%$ (subspecies Lapland). Moreover, in the Lapland subspecies, more than half $(59.9 \%)$ in this group is occupied by $\alpha$-pinene, and 3 -carene is 3 times less $(18.1 \%)$. In the Siberian subspecies, this ratio is 2.4 : $1(47.6 \%$ versus $19.7 \%)$, in the forest-steppe subspecies - 2.0:1 (49.5\% versus $24.7 \%)$.

Sesquiterpenes are also widely represented in Scots pine needles of various 
geographic origins. It should be noted that in the pine needles of the European Eastern variety, their content exceeds the proportion of monoterpenes (53.7\% versus $44.2 \%)$. An excess of sesquiterpenes $(52.8 \%$ versus $44.1 \%)$ over monoterpenes was also noted in the foreststeppe subspecies. This ratio is practically at the same level (43.4\% versus $44.1 \%)$ in the Siberian subspecies of Scots pine. In other variants, there is a noticeable excess of monoterpenes over sesquiterpenes $-62.3 \%$ versus $33.2 \%$ in the Lapland pine and $61.7 \%$ versus $34.6 \%$ in the European western variety. In general, for the European subspecies, the content of monoterpenes exceeds that of sesquiterpenes $(57.3 \%$ versus $39.4 \%$ ).

It is also important that the noted fact that in various subspecies and varieties of Scots pine in the group composition of sesquiterpenes, there is an excess of one component in the composition $\delta$-cadinene - from $15.5 \%$ in the variety of European Scots pine to $22.1 \%$ in the Siberian subspecies.

Conclusions and future perspectives. As a result of the work done, the composition of the main components of the essential oil from the group of monoterpenes, sesquiterpenes and the oxygencontaining group was revealed, inhomogeneous in content, among various subspecies and climatypes of Scots pine growing in geographical forest cultures on the territory of the Negorelsk educational and experimental forestry enterprise (Minsk region, Republic of Belarus). The data obtained on the composition of the essential oil and the ratio of a number of components within or from different groups in it will make it possible in the future to select the most promising climatic ecotypes for breeding for resistance to biotic and abiotic environmental factors, taking into account the productivity indicators of climatic stands, quality of trunks, assessment of the vital state of trees in the plantation and their safety.

\section{References}

Babkyn, V. A., et al. (2011). Biomass larch: the chemical composition to innovative products. Novosibirsk: SO RAN [in Russian].

Babkyn, V. A. (2017). Extractive substances of larch wood: chemical composition, biological activity, prospects for practical use. Innovation and expertise, 2 (20), 210-223 [in Russian].

Brytton, H. (1986). Biochemistry of natural pigments. Moscow: Myr, 42 [in Russian].

Crozier, A., et al. (2006). Plant secondary metabolites: occurrence, structure and role in the human diet. Oxford: Blackwell Publishing Ltd.

Deruma, V. Ya. (1983). Basic principles of selection and preparation of samples of greenery for the study of its chemical composition. Study of the chemical composition of woody greenery. Methodical bases. Ryha: Zynatne [in Russian].

Esiakova, O. A., \& Stepen, R. A. (2008). Indication of air pollution in Krasnoyarsk by morphometric and chemical parameters of Siberian spruce needles. Chemistry of plant raw materials, 1, 143-148 [in Russian].
Kheldt, H. V. (2011). Biochemistry of plants: Moscow: BINOM. Knowledge laboratory [in Russian].

Kheftman, E. (1986). Chromatography. Practical application of the method. Part 1. Moscow: Myr [in Russian].

Kivanç, A., \& Akgül, A. (1986). Antibakterial activities essential oils from Turish spices and citrus. Flavour and fragrans Journal, 1 (45), 175-179. http://doi.org/10.1002/ ffj. 2730010409

Kolesnykov, V. L. (2003). Mathematical foundations of computer modeling of chemicaltechnological systems: textbook. manual for university students. Minsk: BHTU [in Russian].

Krasylnykova, L. A., et al. (2004). Plant biochemistry. Kharkov: Torsynh [in Russian].

Kretovych, V. (1986). Plant biochemistry. Moscow: Vysh. shk. [in Russian].

Kruk, N. K., Nosnykov, V. V., \& Rabko, S. V. (2019). Current state, problems and prospects for reforestation in Belarus. In Forest restoration and forest melioration in Ukraine: beginning, current state, challen- 


\section{С. В. Ребко, Л. Ф. Поплавська, С. А. Ламоткін, \\ І. В. Кімейчук, В. М. Хрик, В. Ю. Юхновський}

ges of the present and prospects in the conditions of the Anthropocene (pp. 417-446). Kyiv: Kondor [in Russian].

Kuzmyn, S. R. (2019). Scots pine needles and wood with varying degrees of resistance to fungal pathogens. In Materials of the $6^{\text {th }}$ International Conference-Meeting "Conservation of Forest Genetic Resources". Shchuchynsk, Respublyka Kazakhstan 1620 September, 2019 (pp. 131-132). Kokshetau: Myr Pechaty [in Russian].

Lamotkyn, S. A., Hyl, E. V., Romaniuk, L. Y., \& Skakovskyi, E. D. (2019). Seasonal dynamics of Picea glauca essential oil terpenoids in urban settings. Plantresources, 55 (2), 259-267 [in Russian].

Leshkov, B. P. (1985). Workshop on plant biochemistry. Moscow: Ahropromyzdat [in Russian].

Lobanov, V. V., \& Stepen, R. A. (2004). Influence of biocenotic factors on the content and composition of fir oil. Coniferous boreal zones, 2, 148-156 [in Russian].

Lovkova, M. Ya. (1981). Biosynthesis and metabolism of alkaloids in plants. Moscow: Nauka, 169 [in Russian].

Maksymov, V. M. (2004). Population structure Pinus sylvestris (Pinaceae) by the composition of monoterpenes in the Central Russian forest-steppe. Abstract of Dr. dissertation for Agricultural Science, 06.03.01 - Forest Inventory and Forest Measurement. Voronezh [in Russian].

Mardarowicz, M., Wianowska, D., Dawidowicz, A. I., \& Sawicki, R. (2004). Comparison of terpen composition in Engelmann spruce (Picea Engelmann) using hydrdistillation. SPME and PLE. Zeitschriftfür Natur forschung, 59 (9-10), 641-648. http://doi. org/10.1515/znc-2004-9-1006

Ostakyn, A. Y. (1989). Application of methods in computers. Planning and processing of experiment results. Minsk: Vysh. Shk. [in Russian].

Pen, R. Z. (1982). Statistical methods for modeling and optimization of pulp and paper production processes. Krasnoiarsk: Krasnoiarsk State Univ. [in Russian].
Pen, R. Z., \& Mencher, E. M. (1973). Statistical methods in the pulp and paper industry. Moscow: Lesnai prom-st [in Russian].

Petrenko, E. S. (1967). Variability of the number of resin channels in the needles of Scots pine. Forestry, 6, 76-83 [in Russian].

Plemenkov, V. V. (2001). Introduction to the chemistry of natural compounds. Kazan: Kazan [in Russian].

Plemenkov, V. V., \& Tevs, O. A. (2014). Biomedical properties and prospects of terpenoids (isoprenoids). Chemistry of plant raw materials, 4, 5-20 [in Russian].

Poltavchenko, Yu. A., \& Rudakov, H. A. (1973). Evolution of biosynthesis of monoterpenes in the pine family. Plant resources, 9 (4), 481-493 [in Russian].

Ponomareva, E. Y., Molokhova, E. Y., \& Kholov, A. K. (2015). The use of essential oils in pharmacy. Modern problems of science and education, 4, 37-45 [in Russian].

Pravdin, L. F. (1964). Scots pine: Variability, intraspecific taxonomy and selection. Moscow: Nauka [in Russian].

Schmidt, A., et al. (2005). Induced chemical defenses in conifers: Biochemical and molecular approaches to studying their function. Amsterdam. Elsevier, 39, 1-28.

Stepen, R. A. (1995). The composition of the essential oil and volatile terpenoids of the shoots Pinus sylvestris L. in Central Siberia. Plant resources, 4, 63-70 [in Russian].

Stepen, R. A. (1999). Ecological and resource significance of volatile terpenoids from pine forests in Central Siberia. Chemistry of plant raw materials, 2, 125-129 [in Russian].

Teissedre, P. L., \& Waterhouse, A. L. (2000). Inhibition of oxidation of human low-density lopoprteibs by phenolic substances in different essential oils varieties. J. Agric. Food Chem, 48 (9), 3801-3805. http://doi. org/10.1021/jf.990921x

Vasylev, A. E. (1977). Functional morphology of plant secretory cells. Leninhrad [in Russian].

\section{Ребко С. В., Поплавська Л. Ф., Ламоткін С. А., \\ Кімейчук І. В., Хрик В. М., Юхновський В. Ю. ВМІСТ ОСНОВНИХ КОМПОНЕНТІВ ЕФІРНОÏ ОЛІЇ У ХВОЇ СОСНИ ЗВИЧАЙНОÏ, ЯКА РОСТЕ У ГЕОГРАФІЧНИХ КУЛЬТУРАХ}

Метою досліджень стало проведення аналізу складу терпенів і встановлення відмінностей за рівнем вмісту ефрірних масел у хвої сосни звичайної різних кліматичних екотипів, які ростуть у географрічних лісових культурах. Об'єкт дослідження представлений 17 кліматипами сосни звичайної, які ростуть у геограсрічних культурах на території Негорільского навчальнодослідного лісгоспу Мінської області Білорусі. Якісний і кількісний аналіз ефрірного масла хвої 
сосни звичайної здійснювали методом газорідинної хроматографії без попереднього фрракціонування на хроматографрі «Кристал 5000.1».

У досліджуваних кліматипів сосни звичайної встановлено різний рівень за складом ефірного масла серед монотерпенів, сесквітерпенів і кисеньвмістної групи, а також виявлено істотні відмінності за вмістом низки компонентів усередині досліджуваних груп. Найбільщий вихід ефрірної олії спостерігається у підвиді сосни звичайної різновиду європейська західна - 1,9\%, трохи нижче цей показник у підвиду лісостепова - 1,7%). Істотно нижчий показник виходу ефрірної олії виявився у сосни звичайної різновиду європейська східна та підвиду сибірська, який становить 1,1 \% і 1,0 \% відповідно.

Отримані дані щодо складу ефірної олії і співвідношення в ній низки компонентів серед підвидів і різновидів сосни звичайної (підвиди: лапландська, сибірська, лісостепова, європейська; різновиди: європейська західна і східна) дадуть змогу в подальшому проводити відбір найбільш перспективних кліматичних екотипів і підвидів для селекції на стійкість до біотичних $i$ абіотичних фракторів середовища з урахуванням показників росту і продуктивності деревостанів.

Відомості про склад компонентів ефрірної олії у хвої кліматипів і підвидів сосни звичайної допоможуть розширити знання щодо стійкості рослин, їх збереження і росту, особливо в умовах зміни клімату в напрямі аридизації.

Ключові слова: компонентний склад, екстрактивні речовини, монотерпени, сесквітерпени, дітерпени, географрічні культури, кліматичний екотип.

Отримано: 2021-03-16 